\title{
Haplotype Diversity of Partial Cytochrome b Gene in Kebumen Ongole Grade Cattle
}

\author{
T. Hartatik*, D. Maharani, J. H. P. Sidadolog, A. Fathoni, \& Sumadi \\ Laboratory of Animal Genetic and Breeding, Department of Animal Breeding and Reproduction, \\ Faculty of Animal Science, Universitas Gadjah Mada, Yogyakarta 55281, Indonesia \\ *Email of corresponding author: tety@ugm.ac.id \\ (Received 24-10-2017; Reviewed 18-12-2017; Accepted 29-01-2018)
}

\begin{abstract}
Cytochrome $b$ gene is commonly used to figure out the genetic variation in animals. This research was designed to explore specific markers of Kebumen Ongole grade cattle and to understand the relationship between Kebumen and Brahman cattle using mtDNA cyt $b$ sequences. The sequence of mtDNA cytochrome $b$ gene of 14 individuals Kebumen Ongole grade cattle and 15 individuals Brahman cattle was determined by using polymerase chain reaction and sequencing with a pair of primer. The haploview software was utilized to linkage disequilibrium (LD) analysis. As a result, 36 SNPs (single nucleotide polymorphisms) with 8 haplotypes were identified in Kebumen Ongole grade cattle. In contrast, a small number of SNPs (7) and haplotypes (6) were observed in Brahman cattle. The homozigosity in Brahman cattle was higher than that in Kebumen Ongole grade cattle cattle. Moreover, based on mtDNA sequences, $50 \%$ of Kebumen Ongole grade cattle had $85 \%$ similarity with Brahman cattle. The SNP number and LD values of Kebumen Ongole grade cattle were greater than those of Brahman cattle. It was presumed that Brahman cattle might be introduced into Kebumen territory. In conclusion, some of Kebumen Ongole grade cattle have genetic relation with Brahman cattle. In addition, the information of SNP and haplotype results from this research can be used as markers to differentiate breeds of animals.
\end{abstract}

Keywords: haplotype, cyt b gene, kebumen ongole grade cattle, linkage disequilibrium

\section{INTRODUCTION}

The genetic diversity of cattle in Indonesia was established as a result of crossbreeding and upgrading since 1930s. Historically, Ongole grade cattle was the result of crossing between Javanese cattle (Bos javanicus) and Ongole cattle (Bos indicus). Ongole grade cattle has a good productivity and resistance to tropical environments. This cattle has a white-gray skin, long tail, black fur around the eyes, short head, short horns, long straight ears, and a rather large belly (Sutarno et al., 2015). Ongole grade cattle in Indonesia is known with the name of Peranakan Ongole (PO). PO cattle is the result of a cross between Java and Sumba Ongole cattle (Suyadi et al., 2014). At present, many breeders cross them with Brahman cattle.

Brahman cattle, originally from Indian Bos indicus, firstly imported into the US since 1849 and it has been crossed with many new breeds. Brahman cattle has a long large body, big shoulders, loose skin, many folds in the lower jaw to the front of chest, longways head, large hanging ears, and large thighs (Sutarno et al., 2015). Brahman cattles were imported into Indonesia in 2006 and distributed to the most areas of Indonesia for supporting beef cattle programe. They were crossed with Ongole grade cattle to produce livestock which have a good productivity and a good adaptability (Sutarno et al., 2015).

In Kebumen, breeding programe to improve genetic quality of PO cattle had been done before 1930 and they look like a pure Ongole cattle (Utomo et al., 2015). Based on physical observation in the field, we found the similarities between Kebumen Ongole grade cattle and Brahman cattle. Kebumen Ongole grade cattle has a bigger body size compared with Indonesian National Standard for Ongole cattle both males and females in other areas. The qualitative characteristics of Kebumen Ongole grade cattle are white body color, black muzzle, black or red vulva, lateral triangle head, long horns, long wattle, and big hump (Sudrajad and Subiharta, 2014). Their population in the District of Kebumen in 2014 was 80,486 heads. They were declared as a local Kebumen cattle strain through the Decision Letter of Indonesian Minister of Agriculture no. 358/Kpts/PK. 040/6/2015 on 8 June 2015.

Based on available records, it was established that Brahman cattle was crossed with Ongole grade cattle in Kebumen, so we proposed that Kebumen Ongole grade cattle and Brahman cattle had blood relationship. Finding out the relationship between both Kebumen 
Ongole grade cattle and Brahman cattle could be through a molecular techniques, one of them was Mitochondrial DNA analysis. Mitochondrial DNA can be used as a marker for the study of animal domestication (Stock et al., 2009). The use of PCR of mitochondrial DNA (mtDNA) is a recent method to identify animal species (Minarovič, et al., 2010). Our previous study (Hartatik et al., 2015) reported that mitochondrial cytochrome $\mathrm{b}(\mathrm{Cyt} b)$ gene fragment also could be used for identification of species origin by the PCR method. The result of PCR showed two different fragments in two species between cattle (472 bp) and buffalo (124 bp) (Munira et al., 2016).

Genetic marker of cyt $b$ genes can be derived from the maternal line and used to determine the origin of a cattle. Romaino et al. (2014) reported that three Malaysian cattle breeds could be distinguished into wild cattle and domestic cattle by the amplification of the Cyt $b$ gene. Several studies on mtDNAs in local cattle of Indonesia have been reported. For examples, local breeds including both Jabres and Rambon cattle in Brebes and Bondowoso Regency, respectively, are similar with Zebu and Bali cattle (Sutarno and Setyawan, 2015). Other results based on mtDNA cyt b marker showed that there were two haplotypes (A and B) of local cattle in Indonesia (Hartatik et al., 2015). Those result showed that both Aceh and Pesisir cattle have haplotype B, while Bali cattle and Limura cattle (cross between Limousin bull and Madura cattle by artificial insemination) have different haplotype (A). However, Madura cattle and Java cattle have both haplotypes (A and B).

Studies using mtDNA can also be connected with development of high-throughput technology. One of the method that can be used for a genome-wide analysis of the non-random connection alleles at different loci named as linkage disequilibrium (LD) (Jasielczuk et al., 2016, Niu et al., 2016). The exploration of LD also can provide important insights for guiding selection in the genomic levels (Brito et al., 2011; Zhou et al., 2013). Previous studies proved that LD levels had effect on the accuracy of genomic prediction (Yang et al., 2012; Cuyabano et al., 2014).

Since there was no study about cyt $b$ gene as DNA markers in Kebumen Ongole grade cattle, this research was designed to explore specific markers of Kebumen Ongole grade cattle and to understand the relationship between Kebumen and Brahman cattle using mtDNA cyt $b$ sequences. This study could contribute to the understanding of genetic variation of another local cattle in Indonesia.

\section{MATERIALS AND METHODS}

\section{Samples and DNA Extraction}

Twenty-nine local cattle were used in the study consisting of Kebumen Ongole grade cattle ( $n=14$ heads) and Brahman cattle ( $\mathrm{n}=15$ heads) as a control. Brahman cattle were used as controls because we wanted to understand the DNA composition of Brahman cattle in Kebumen Ongole grade cattle. Blood samples of Kebumen Ongole grade cattle were collected based on their phenotypic characteristics which were close to that of Brahman cattle. Blood samples of Brahman cattle was collected from BPTUHPT Sembawa (Lampung). All the blood samples used in this study were taken from female cattle. The blood samples were collected from all animals from jugular vein with $22 \frac{1}{2} \mathrm{G}$ needle and collected in K3EDTA tubes, then the collected samples were stored at $-20^{\circ} \mathrm{C}$. Then, about $3 \mathrm{~mL}$ of blood samples were also collected for genomic DNA isolation using gSYNC ${ }^{\mathrm{TM}}$ DNA Extraction Kit (Genetika Science).

\section{Polymerase Chain Reaction (PCR)}

The amplification of DNA samples in this study was conducted by following the method modified by Hartatik et al. (2015). The primers used in this study were forward 5'-AAAAACCACCGTTGTTATTCAACTA-3' and reverse 5'-GCCCCTCAGAATGATATTTGTCCTCA3' (Wolf et al., 1999). The total volume of $30 \mu \mathrm{L}$ of PCR mixture were prepared and amplified by using the program: pre-denaturation for $2 \mathrm{~min}$ at $94{ }^{\circ} \mathrm{C}$, denaturation at $95{ }^{\circ} \mathrm{C}$ for $36 \mathrm{~s}$, annealing at $51{ }^{\circ} \mathrm{C}$ for $73 \mathrm{~s}$, extension at $72{ }^{\circ} \mathrm{C}$ for $84 \mathrm{~s}$, and final extension at $72{ }^{\circ} \mathrm{C}$ for 35 cycles for 3 min by Primus-25 Advanced (Germany) Thermal Cycler machine. The PCR products were visualized by $1 \%$ agarose gel electrophoresis under UV light. The expected product size of cytochrome b gene was $464 \mathrm{bp}$ according to reference GenBank Acc.No. JN817304, Bos indicus (Figure 1A).

\section{Squencing Analysis}

PCR products with a total volume of $30 \mu \mathrm{L}$ from each sample were sent to the 1st Base Genetic Science. Sequencing process used BigDye ${ }^{\circledR}$ Terminator v3.1 Cycle Sequencing Kit with the machine of ABI PRISM 3730xl Genetic Analyzer developed by Applied Biosystems, USA. One direct sequence analysis was carried out by using the forward primer of cyt $b$ gene. The results of the sequencing were then analyzed by using Bioedit 7.5 to determine the SNP and haplotype from both groups of cattle.

\section{Linkage Disequilibrium Analysis}

Relationships between the SNPs to be recommended to form haplotype were estimated using LD analysis by haploview software version 4.2 (Broad Institute). Recommended haplotype pairs were the pairs having the values of $\mathrm{D}^{\prime}$ and $\mathrm{R}^{2}$ above $75 \%$. Haploview software was used in this study by following method modified by Barret et al. (2005).

\section{RESULTS}

\section{Sequencing Analysis}

The result of PCR product size in 29 samples were medium to high intensity. The results of PCR $464 \mathrm{bp}$ with the flanking primer of cytochrome $b$ gene can be seen in Figure 1. Further analysis using PCR product 
A

Forward Primer

AAAAACCATCGTTGTCATTCAACTACAAGAACACTAATGACTAACATTCGAAAGTCCCAC CCACTAATAAAAATTGTAAACAATGCATTCATCGACCTTCCAGCCCCATCAAACATTTCAT CATGATGAAATTTCGGTTCCCTCCTGGGAATCTGCCTAATCCTACAAATCCTCACAGGCCT ATTCCTAGCAATACACTACACATCCGACACAACAACAGCATTCTCCTCTGTTACCCATATC TGCCGAGACGTGAACTACGGCTGAATCATCCGATACATACACGCAAACGGAGCTTCAAT GTTTTTTATCTGCTTATATATGCACGTAGGACGAGGCTTATATTACGGGTCTTACACTTTT CTAGAAACATGAAATATTGGAGTAATCCTTCTGCTCACAGTAATAGCCACAGCATTTATA GGATACGTCCTACCATGAGGACAAATATCATTCTGAGGAGC Reverse Primer

B

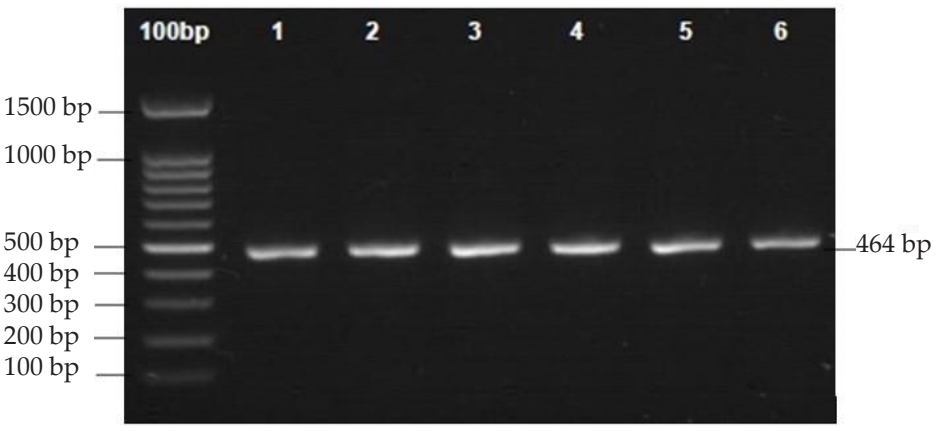

Figure 1. The predicted sequence result (A) and 464 bp product size PCR of Cyt-b gene (B)

\begin{tabular}{|c|c|c|c|c|c|c|c|c|c|c|c|c|c|c|c|c|c|c|c|c|c|c|c|c|c|c|c|c|c|c|c|c|c|c|c|c|c|}
\hline \multirow{2}{*}{ Sample } & \multicolumn{37}{|c|}{ Single Nucleotide Polymorphism (1-36) } \\
\hline & 1 & 2 & 3 & 4 & 5 & 6 & 7 & 8 & 9 & 0 & 1 & 2 & 3 & 4 & 5 & 6 & 7 & 8 & 9 & 0 & 1 & 2 & 3 & 4 & 5 & 6 & 7 & 8 & 9 & 0 & 1 & 2 & 3 & 4 & 5 & 6 & $\mathrm{H}$ \\
\hline CP1 & 3 & 4 & 4 & 2 & 3 & 3 & 2 & 1 & 3 & 2 & 1 & 4 & 2 & 4 & 4 & 3 & 3 & 4 & 4 & 4 & 4 & 4 & 3 & 3 & 3 & 4 & 3 & 3 & 3 & 4 & 1 & 4 & 4 & 4 & 4 & 2 & I \\
\hline Cp7 & 3 & 4 & 4 & 2 & 3 & 3 & 2 & 1 & 3 & 2 & 1 & 4 & 2 & 4 & 4 & 3 & 3 & 4 & 4 & 4 & 4 & 4 & 3 & 3 & 3 & 4 & 3 & 3 & 3 & 4 & 1 & 4 & 4 & 4 & 4 & 2 & I \\
\hline Cp2 & 3 & 4 & 4 & 2 & 3 & 3 & 2 & 1 & 3 & 2 & 1 & 4 & 2 & 4 & 4 & 3 & 3 & 4 & 4 & 4 & 4 & 4 & 3 & 3 & 3 & 4 & 3 & 3 & 3 & 4 & 1 & 4 & 4 & 4 & 4 & 4 & II \\
\hline Cp4 & 3 & 4 & 4 & 2 & 3 & 3 & 2 & 1 & 3 & 2 & 1 & 4 & 2 & 4 & 4 & 3 & 3 & 4 & 4 & 4 & 4 & 4 & 3 & 3 & 3 & 4 & 3 & 3 & 3 & 4 & 1 & 4 & 4 & 4 & 4 & 4 & II \\
\hline Cp5 & 3 & 4 & 4 & 2 & 3 & 3 & 2 & 1 & 3 & 2 & 1 & 4 & 2 & 4 & 4 & 3 & 3 & 4 & 4 & 4 & 4 & 4 & 3 & 3 & 3 & 4 & 3 & 3 & 3 & 4 & 1 & 4 & 4 & 4 & 4 & 4 & II \\
\hline Cp8 & 3 & 4 & 4 & 2 & 3 & 3 & 2 & 1 & 3 & 2 & 1 & 4 & 2 & 4 & 4 & 3 & 3 & 4 & 4 & 4 & 4 & 4 & 3 & 3 & 3 & 4 & 3 & 3 & 3 & 4 & 1 & 4 & 4 & 4 & 4 & 4 & II \\
\hline Cp11 & 3 & 4 & 4 & 2 & 3 & 3 & 2 & 1 & 3 & 2 & 1 & 4 & 2 & 4 & 4 & 3 & 3 & 4 & 4 & 4 & 4 & 4 & 3 & 3 & 3 & 4 & 3 & 3 & 3 & 4 & 1 & 4 & 4 & 4 & 3 & 4 & III \\
\hline Cp13 & 3 & 4 & 4 & 2 & 3 & 3 & 2 & 1 & 3 & 2 & 1 & 4 & 2 & 4 & 4 & 3 & 3 & 4 & 3 & 4 & 4 & 4 & 3 & 3 & 3 & 4 & 3 & 3 & 3 & 4 & 1 & 4 & 4 & 4 & 4 & 2 & IV \\
\hline Cp14 & 4 & 3 & 3 & 1 & 4 & 4 & 1 & 1 & 4 & 1 & 3 & 3 & 1 & 3 & 3 & 4 & 4 & 3 & 4 & 3 & 3 & 3 & 4 & 4 & 3 & 4 & 4 & 4 & 4 & 4 & 2 & 3 & 3 & 3 & 4 & 4 & $\mathrm{~V}$ \\
\hline Cp3 & 4 & 3 & 3 & 1 & 4 & 4 & 1 & 2 & 4 & 1 & 3 & 3 & 1 & 3 & 3 & 4 & 4 & 3 & 4 & 3 & 3 & 3 & 4 & 4 & 4 & 4 & 4 & 4 & 4 & 3 & 2 & 3 & 3 & 3 & 4 & 4 & VI \\
\hline Cp10 & 4 & 3 & 3 & 1 & 4 & 4 & 1 & 2 & 4 & 1 & 3 & 3 & 1 & 3 & 3 & 4 & 4 & 3 & 4 & 3 & 3 & 3 & 4 & 4 & 4 & 4 & 4 & 4 & 4 & 3 & 2 & 3 & 3 & 3 & 4 & 4 & VI \\
\hline Cp12 & 4 & 3 & 3 & 1 & 4 & 4 & 1 & 2 & 4 & 1 & 3 & 3 & 1 & 3 & 3 & 4 & 4 & 3 & 4 & 3 & 3 & 3 & 4 & 4 & 4 & 4 & 4 & 4 & 4 & 3 & 2 & 3 & 3 & 3 & 4 & 4 & VI \\
\hline Cp6 & 4 & 3 & 3 & 1 & 4 & 4 & 1 & 2 & 4 & 1 & 3 & 3 & 1 & 3 & 3 & 4 & 4 & 3 & 4 & 3 & 3 & 3 & 4 & 4 & 4 & 4 & 4 & 4 & 4 & 3 & 2 & 3 & 3 & 3 & 4 & 2 & VII \\
\hline Cp9 & 4 & 3 & 3 & 1 & 4 & 4 & 1 & 2 & 4 & 1 & 3 & 3 & 1 & 3 & 3 & 4 & 4 & 3 & 4 & 3 & 3 & 3 & 4 & 4 & 4 & 3 & 4 & 4 & 4 & 3 & 2 & 3 & 3 & 3 & 4 & 4 & VIII \\
\hline
\end{tabular}

Figure 2. Identification of haplotype marker based on Cyt b gen in Kebumen Ongole grade cattle

was direct sequencing by one site of forward primer. The results of sequencing analysis showed 36 SNPs with 8 haplotypes in Kebumen Ongole grade cattle (Figure 2) and 7 SNPs with 6 haplotypes in Brahman cattle (Figure 3). Four samples of fifteen Brahman samples had SNP which located at 3 different places from the SNP on beef PO Kebumen. There were 2 samples (CB9/H-VI and $\mathrm{CB} 12 / \mathrm{H}-\mathrm{V})$ with nucleotide changes from Guanine to Adenine, then on the two and three positions respectively (CB15/H-IV and CB7/H-III) Cytocin changed into Adenine and Guanine changed into Adenine (Figure 4 , on the last 4 lines). The 11 other samples could be divided into two groups of haplotype, namely $\mathrm{H}-\mathrm{I}$ (CB1, CB2, CB3, CB10, CB11, and CB14) and H-II (CB4, CB5, CB6, CB8, and CB8). While 4 SNPs of 7 SNPs on 11 samples of the Brahman cattle were located at the same locus of the 4 SNPs of Kebumen Ongole grade cattle. So, the 4 SNPs included in the 36 SNPs in Kebumen Ongole grade cattle were identified.

\begin{tabular}{|c|c|c|c|c|c|c|c|c|}
\hline \multirow{2}{*}{ Sample } & \multicolumn{7}{|c|}{ Single Nucleotide Polymorphism (1-7) } & \multirow{2}{*}{ H } \\
\cline { 2 - 8 } & 1 & 2 & 3 & 4 & 5 & 6 & 7 & \\
\hline CB 1 & 2 & 1 & 3 & 3 & 4 & 2 & 4 & I \\
\hline CB 2 & 2 & 1 & 3 & 3 & 4 & 2 & 4 & I \\
\hline CB 3 & 2 & 1 & 3 & 3 & 4 & 2 & 4 & I \\
\hline CB 5 & 2 & 1 & 3 & 3 & 4 & 2 & 4 & I \\
\hline CB 10 & 2 & 1 & 3 & 3 & 4 & 2 & 4 & I \\
\hline CB 11 & 2 & 1 & 3 & 3 & 4 & 2 & 4 & I \\
\hline CB 14 & 2 & 1 & 3 & 3 & 4 & 2 & 4 & I \\
\hline CB 4 & 2 & 2 & 4 & 3 & 3 & 2 & 2 & II \\
\hline CB 6 & 2 & 2 & 4 & 3 & 3 & 2 & 2 & II \\
\hline CB 8 & 2 & 2 & 4 & 3 & 3 & 2 & 2 & II \\
\hline CB 13 & 2 & 2 & 4 & 3 & 3 & 2 & 2 & II \\
\hline CB 7 & 2 & 1 & 3 & 3 & 4 & 1 & 4 & III \\
\hline CB 15 & 2 & 1 & 3 & 1 & 4 & 2 & 4 & IV \\
\hline CB 12 & 1 & 1 & 3 & 3 & 4 & 2 & 4 & V \\
\hline CB 9 & 1 & 2 & 4 & 3 & 3 & 2 & 2 & VI \\
\hline
\end{tabular}

Figure 3. Identification of haplotype based on Cyt $\mathrm{b}$ gene in Brahman cattle 


\section{Comparative Haplotype Analysis between Kebumen Ongole Grade Cattle and Brahman Cattle}

Comparative analysis of haplotypes between Kebumen Ongole grade cattle and Brahman cattle can be seen in Figure 4. There were 8 haplotypes in Kebumen Ongole grade cattle and 6 haplotypes in Brahman cattle in this study. Haplotype $\mathrm{V}$ in Kebumen Ongole grade cattle was similar with haplotype I on Brahman cattle. It was presumed that haplotype $\mathrm{V}$ in Kebumen Ongole grade cattle came from Brahman cattle's dam. These results can be used as the basis of recommendations in germ selection to be developed as the dams. The percentage of haplotype for Kebumen Ongole grade cattle were successively haplotype I (14.29\%), II (28.57\%), III (7.14\%), IV (7.14\%), V (7.14\%), VI (21.43\%), VII (7.14\%), and VIII $(7.14 \%)$. While the results of the identification of haplotype for Brahman cattle were successively hap- lotype I (46.67\%), II (26.67\%), III (6.67\%), IV (6.67\%), V $(6.67 \%)$, and VI $(6.67 \%)$.

\section{Results of Lingkage Disequilibrium (LD) Analysis}

The results of the LD analysis for Brahman cattle were presented in Figure 5. The results showed that there were 21 SNP variation pairs on Brahman cattle. From the 21 SNP variation pairs, $28.57 \%$ of SNPs had high values for LD $(>8)$ and $71.43 \%$ having low LD values. The pairs with high LD values in Figure 6 are marked with black ( $\mathrm{D}^{\prime}$ and $\mathrm{R} 2$ value $\left.=1\right)$. It means that the relationships between SNPs have a maximum value $(100 \%)$. The low LD values were marked with white and gray. Based on the result, there were 4 kinds of SNP that were recommended to be used i.e., SNP 2, 3, 5, and 7. SNP 1, 4, and 6 were not recommended because of each SNP that paired with another SNP generated the low values of D' and $R$.
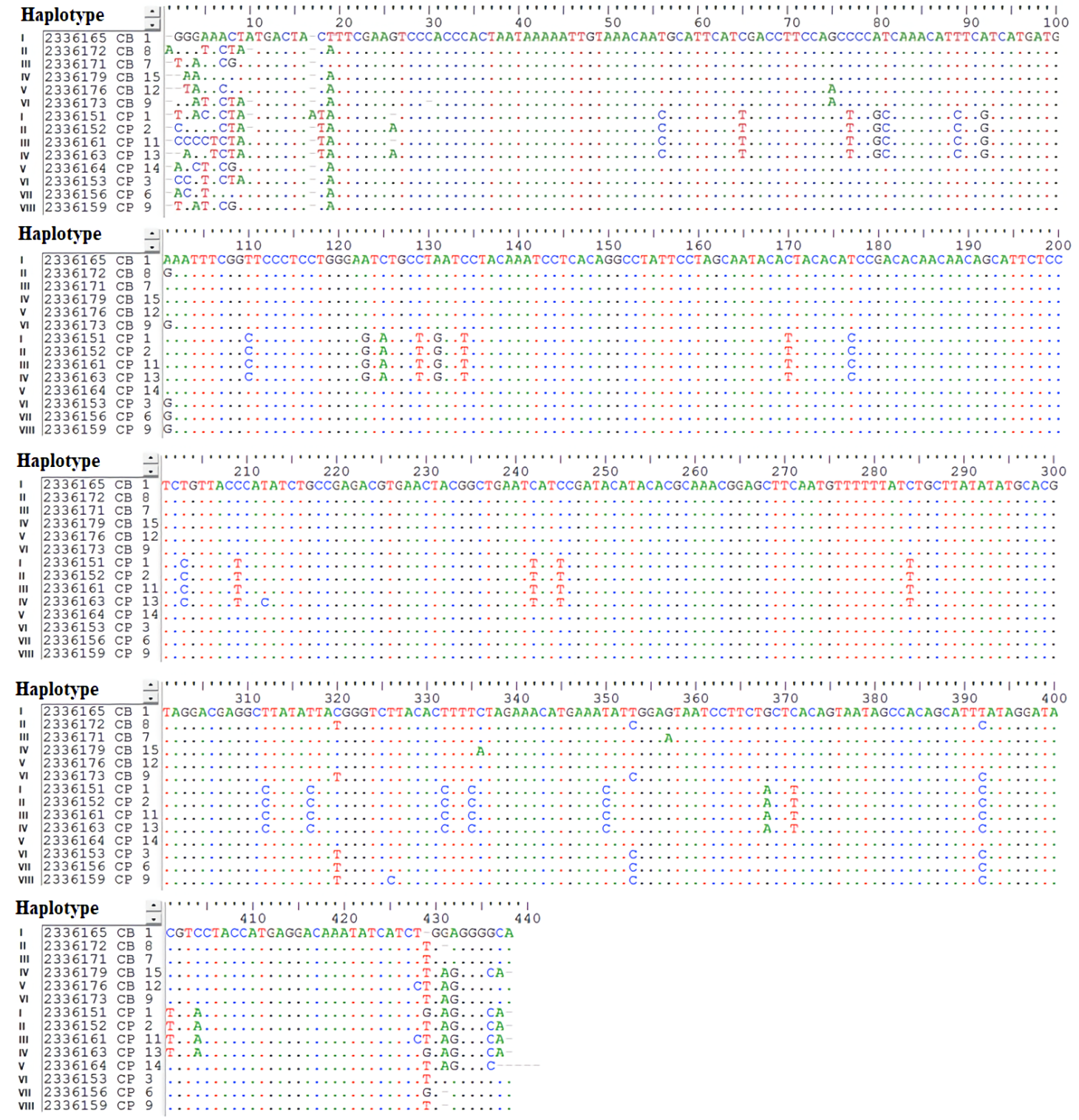

Figure 4. The haplotypes of cyt b sequence in Kebumen Ongole grade cattle and Brahman cattle 
The result of LD analysis on Kebumen Ongole grade cattle using 34 SNP variations generated a total of 562 pairs SNP. A total of $72.37 \%$ SNP had high values of LD. There were three pairs of SNP having high value of $\mathrm{R}^{2}$ but their LD values were low (SNP 7-24, 7-29, 2429), so they were also not recommended. SNP 7, 18, 24, 25, and 29 in Kebumen Ongole grade cattle were not recommended because of producing the low values of $\mathrm{LD}$ and $\mathrm{R}$. The results of the LD analysis for Kebumen Ongole grade cattle were presented in Figure 6. The illustration at Figure 6 shows the visible shades of gray with numbers 74 indicating the variation values of $D$ $(>80 \%)$, it means they are of reasonable strength but not maximum. While the white color is the haplotype pairs with the low values of $\mathrm{R}^{2}$ and $\mathrm{D}^{\prime}$.

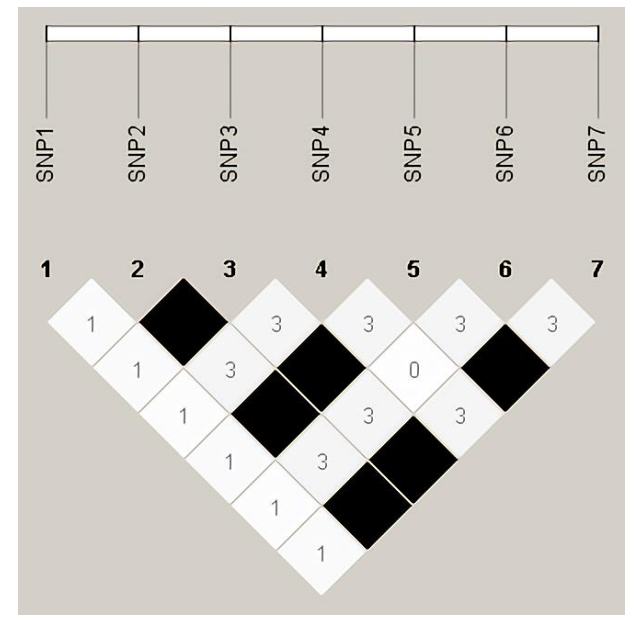

Figure 5. The plot of linkage disequilibrium (LD) of the cyt $b$ gene SNPs in Brahman Cattle estimated using the haploview software

\section{DISCUSSION}

Mitochondrial DNA has been commonly used as genetic markers for identification and characterization because it is stronger than nuclear DNA (Chung, 2013). Identified target of single nucleotide polymorphism in the mtDNA Cyt-b gene was derived from multiple alignments of Gen-Bank sequences (accession No. AF492350, AY126697, JN817304, JN817303, JN817330, JN81730, and GU256940). The results of mtDNA Cyt b gene alignment showed five types of haplotype (data were not shown). Haplotype was the combinations of alleles which present on each of the two homologous chromosomes in a diploid individual (Miar et al. 2016). Hartatik et al. (2014) reported that there were only two haplotypes (A and B) found in Indonesian local cattle. The higher total number of haplotype was shown by Chung et al. (2013) in Korean Native Cattle and Japanese Black cattle i.e., 10 and 14, respectively. Difference of the number haplotype could be due to the differences of the samples used in the study.

In the present study, sequencing analysis on mtDNA cyt-b gene showed 36 SNPs with 8 haplotypes within Kebumen Ongole grade cattle (Figure 2) and 7 SNPs with 6 haplotypes within Brahman cattle. Chung (2013) reported a lower number of SNP in Korean Native Cattle (KNC) i.e., 29 SNPs between cattle populations. The SNP number in cyt b genes could be used for predicting genetic diversity (Cai et al., 2007).

There were 29 SNPs out of 36 SNPs in Kebumen Ongole grade cattle which were different from the SNP in Brahman cattle. The other 7 SNPs out of 36 SNPs in Kebumen Ongole grade cattle had the same variation on both types of cattle. One of the Kebumen Ongole grade cattle samples had $100 \%$ similarities to Brahman cattle, which meant that Kebumen Ongole grade cattle had the

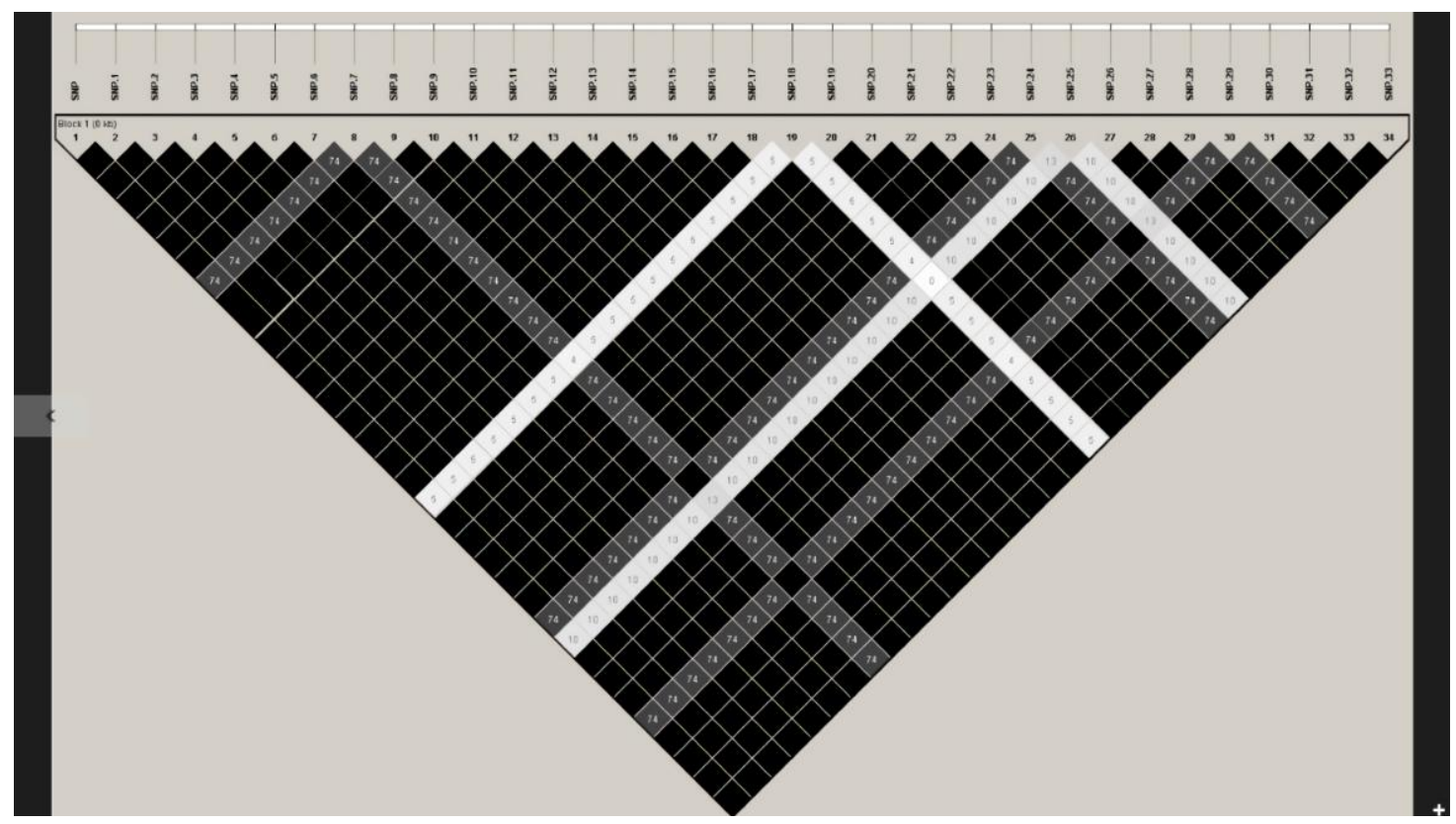

Figure 6. The plot of linkage disequilibrium (LD) of the cyt b gene SNPs in Kebumen Ongole grade cattle estimated using the haploview software 
same nucleotide with Brahman cattle. This result probably indicated that Kebumen Ongole grade cattle which have the same sequence with Brahman cattle have the same origin of maternal inheritance. Thus, these SNP could be used to detect the purity of Kebumen Ongole grade cattle. Chung (2013) reported that the whole sequences of mtDNA could be used to understand the relationship between two different breeds of cattle. Kebumen Ongole grade cattle with haplotype V (CP14) had $100 \%$ similarities with haplotype I (CB 1, 2, 3, 10, 11) on Brahman cattle (Figure 3-4). These results strengthen the argument that there is a relationship between them. The other results also showed that $50 \%$ of Kebumen Ongole grade cattle (7 of 14 samples) had the same mtDNA sequence with Brahman cattle i.e., 85\% identical. Sutarno \& Setyawan (2015) reported that in 2006, Brahman cattle was massively distributed throughout Indonesia to support the government program. Artificial insemination by Brahman semen was more interesting because of fast-growing livestock product.

LD also useful for marker assisted selection (MAS), quantitative trait loci (QTL) mapping, parentage testing, and fine mapping of genetic diseases (Espigolan et al., 2013). The value of LD will be higher when crossing inbred lines and lower when crossing breeds undifferentiated in gene frequencies (Jasielczuk et al., 2016). We present LD statistics in the diagram based on $\mathrm{r}^{2}$ values using the haploview software. Measuring the LD, D', and $\mathrm{r}^{2}$ were used to predict LD value between markers (Gurgul et al., 2014). $\mathrm{R}^{2}$ parameter had better interpretable measure of LD (Qanbari et al., 2010). The influence of allele frequency against $\mathrm{r}^{2}$ also lower compared to $\mathrm{D}^{\prime}$ in a limited population (Mokry et al., 2014).

The results of the LD analysis for Brahman cattle showed 21 SNP variations and $28.57 \%$ of SNPs had high values for $\mathrm{LD}\left(\mathrm{D}^{\prime}>8\right)$ and $71.43 \%$ having low $\mathrm{LD}$ values. The result of LD analysis in Kebumen Ongole grade cattle generated a total of 562 SNP pairs and $72.37 \%$ SNP having high values of LD. The pairs with high LD values marked in black ( $\mathrm{D}^{\prime}$ and $\mathrm{R}^{2}$ value $=1$ ) and the low LD values were marked in white and gray. The previous LD analysis study in Limousin, Simmental, and Polish Red cattle had generated a higher SNP panel, namely, 40,158, 40,117, and 42,118, respectively (Jasielczuk et al., 2016). A group of 4,525 SNPs were observed and used for LD analysis in Hanwoo cattle (Lee et al., 2011). The different in the number of SNP pairs could be caused by the cattle breeds and the number of samples used in these studies.

In this study, $28.57 \%$ SNP of Brahman and $72.37 \%$ SNP of Kebumen cattle had high values of LD (D' and $\mathrm{R}^{2}$ value $=1$ ). This result was higher than $\mathrm{LD}$ which observed in Limousin, Simmental, and Polish Red cattle which were $0.27,0.01$, and 0.02 , respectively (Jasielczuk et al., 2016). Other studies of LD in eight breeds of cattle (Angus, Charolais, Dutch Black, White Dairy, Holstein, Limousin, Nelore, Brahman, and Japanese Black cattle) were shown to be not more than 0.5 (McKay et al., 2007). We recommended these SNP which had the higher value of LD to be used for the analysis of selection intensity and general level of genetic diversity.

\section{CONCLUSION}

Kebumen Ongole grade and Brahman cattle had blood relations based on mtDNA Cyt b. The number of SNP and the value of LD on Kebumen Ongole grade cattle was greater than Brahman cattle. Therefore, the information on SNP and haplotype can be used as a marker to differentiate between Kebumen cattle and Brahman cattle.

\section{REFERENCES}

Barrett, J. C., B. Fry, J. Maller, \& M. J. Daly. 2005. Haploview: analysis and visualization of LD and haplotype maps. Bioinformatics. 21:263-265. https://doi.org/10.1093/ bioinformatics/bth 457

Brito, F., J. Neto, M. Sargolzaei, J. Cobuci, \& F. Schenkel. 2011. Accuracy of genomic selection in simulated populations mimicking the extent of linkage disequilibrium in beef cattle. BMC Genet. 12 : 1-10. https://doi. org/10.1186/1471-2156-12-80

Cai, X., H. Chen, C. Lei, S. Wang, K. Xue, \& Zhang, B. 2007. mtDNA diversity and genetic lineages of eighteen cattle breeds from Bos taurus and Bos indicus in China. Genetica. 131: 175-183. https://doi.org/10.1007/ s10709-006-9129-y

Chen, S. Y., Y. P. Liu, \& Y. G. Yao. 2010. Species authentication of commercial beef jerky based on PCR-RFLP analysis of the mitochondrial 12S rRNA gene. J. Genet. Genomics 37: 763-769. https://doi.org/10.1016/S1673-8527(09)60093-X

Chung, H. 2013. Phylogenetic analysis and characterization of mitochondrial DNA for Korean native cattle. Open Journal of Genetics. 3:12-23. https://doi.org/10.4236/ ojgen.2013.31003

Cuyabano, B., G. Su, \& M. Lund. 2014. Genomic prediction of genetic merit using LD-based haplotypes in the Nordic Holstein population. BMC Genom. 15(1171) : 1-11. https:// doi.org/10.1186/1471-2164-15-1171

Espigolan, R., F. Baldi, A. A. Boligon, F. R. P. Souza, D. G. M. Gordo, R. L. Tonussi, D. F. Cardoso, H. N. Oliveira, H. Tonhati, M. Sargolzaei, F. S. Schenkel, R Carvalheiro, J. A. Ferro, \& L. G. Albuquerque. 2013. Study of whole genome linkage disequilibrium in Nellore cattle. BMC Genom. 14: 1-8. https://doi.org/10.1186/1471-2164-14-305

Gurgul, A., E. Semik, K. Pawlina, T. Szmatoła, I. Jasielczuk, \& M. Bugno-Poniewierska. 2014. The application of genome-wide SNP genotyping methods in studies on livestock genomes. J. Appl. Genet. 55:197-208. https://doi. org/10.1007/s13353-014-0202-4

Hartatik, T., T. S. M. Widi, S. D. Volkandari, D. Maharani, \& Sumadi. 2014. Analysis of DNA Polymorphism in SRY Gene of Madura Cattle Populations. Procedia Environ. Sci. 20:365-369. https://doi.org/10.1016/j.proenv.2014.03.046

Hartatik, T., W. B. P. Putra., S. D. Volkandary, \& Sumadi. 2015. Polymorphism of mtDNA Cytochrome b Gene of Local Cattle in Indonesia. J-SustaiN 3:1-24. https://doi. org/10.24910/jsustain/3.1/2124

Jasielczuk, I., A. Gurgul, T. Szmatoła, T. Ząbek, K. Pawlina, E. Semik, \& M. Bugno Poniewierska. 2016. Linkage disequilibrium and haplotype block structure in Limousin, Simmental and native Polish Red cattle. Livestock Science. 191: 57-63. https://doi.org/10.1016/j.livsci.2016.07.008

Lee, S. H., Y. M. Cho, D. Lim, H. C. Kim, B. H. Choi, H. S. Park, O. H. Kim, S. Kim, T. H. Kim, D. Yoon, \& S. K. Hong. 2011. Linkage Disequilibrium and Effective Population Size in Hanwoo Korean Cattle. Asian-Aust. J. Anim. Sci. 24: 1660 - 1665. 
McKay, S. D., R. D. Schnabel, B. M. Murdoch, L. K. Matukumalli, J. Aerts, W. Coppieters, D. C. E. D. Neto, C. A. Gill, C. Gao, H. Mannen, P. Stothard, Z. Wang, C. P. V. Tassell, J. L. Williams, J. F. Taylor, \& S. S. Moore. 2007. Whole genome linkage disequilibrium maps in cattle. BMC Genetics. 8:1-12. https://doi.org/10.1186/1471-2156-8-74

Miar, Y., M. Sargolzaei, \& Flavio Schenkel. 2014. Haplotype phasing in dairy cattle. Dairy Cattle Breeding and Genetic s Committee, Guelph.

Minarovič, T., A. Trakovická, A. Rafayová, \& Z. Lieskovská. 2010. Animal Species Identification by PCR - RFLP of Cytochrome b. Animal Science and Biotechnologies. 43: $296-299$.

Mokry, F. B., M. E. Buzanskas, M. A. Mudadu, D. A. Grossi, R. H. Higa, R. V. Ventura, A. O. Lima, M. Sargolzaei, S. L. C. Meirelles, F. S. Schenkel, M. V. Silva, S. C. M. Niciura, M. M. Alencar, D. P. Munari, \& L. C Almeida Regitano. 2014. Linkage disequilibrium and haplotype block structure in composite beef cattle breed. BMC Genom. 15: 1-9. https://doi.org/10.1186/1471-2164-15-S7-S6

Munira, S., F. T. Jahura, Md. M. Hossain, \& M. Shamsul A. Bhuiyan. 2016. Molecular detection of cattle and buffalo species meat origin using mitochondrial cytochrome $\mathrm{b}$ $(C y t b)$ gene. Asian J. Med. Biol. Res. 2:177-182. https://doi. org/10.3329/ajmbr.v2i2.29008

Niu, H., B. Zhu, P. Guo, W. Zhang, J. Xue, Y. Chen, L. Zhang, H. Gao, X. Gao, L. Xun, \& J. Lin. 2016. Estimation of linkage disequilibrium levels and haplotype block structure in Chinese Simmental and Wagyu beef cattle using high-density genotypes. Livest. Sci. 190:1-9. https://doi. org/10.1016/j.livsci.2016.05.012

Qanbari, S., E. C. G. Pimentel, J. Tetens, G. Thaller, P. Lichtner, A. R. Sharifi, \& H. Simianer. 2010. The pattern of linkage disequilibrium in German Holstein cattle. Anim. Genet. 41: 346-356.

Romaino, S. M. N. , Z. A. Fazly-Ann , S. S. Loo , M. M. Hafiz , M. D. Hafiz , M. I. Iswadi , P. Kashiani , M. K. A. Rosli , S. M. F. Syed-Shabthar , B. M. Md-Zain, \& O. Abas-Mazni. 2014. Species identification of Malayan Gaur, KedahKelantan and Bali cattle using polymerase chain reactionrestricted fragment length polymorphism. Genet. Mol. Res. 13: 406-414. https://doi.org/10.4238/2014.January.21.8
Stock, F., C. J. Edwards, R. Bollongino, E. K. Finlay, J. Burger, \& D. G. Bradley. 2009. Cytochrome b sequences of ancient cattle and wild ox support phylogenetic complexity in the ancient and modern bovine populations. Anim. Genet. 40:694700. https://doi.org/10.1111/j.1365-2052.2009.01905.x

Sudrajad, P. \& Subiharta. 2014. Karakteristik fenotipik sapi betina Peranakan Ongole Kebumen. Widyariset. 17:283-290.

Septian, W. A., Jakaria, \& C. Sumantri. 2015. Genetic diversity of Bali cattle based on microsatellite marker in Indonesian breeding centre. Med. Pet. 38:12-17. https://doi.org/10.5398/ medpet.2015.38.1.12

Sutarno \& A. D. Setyawan. 2015. Review: Genetic diversity of local and exotic cattle and their crossbreeding impact on the quality of Indonesian cattle. Biodiversitas:16:327-354.

Sutarno, A. D. Setyawan, \& A. J. Lymbery. 2015. Genetic diversity of five Indonesian native cattle breeds at microsatellite loci. Asian J. Anim. Sci. 9:57-64. https://doi.org/10.3923/ ajas.2015.57.64

Suyadi S, Hakim L, S. Wahjuningsih, \& H. Nugroho. 2014. Reproductive performance of Peranakan Ongole (PO) and Limousin $x$ PO Crossbreed (Limpo) cattle at different altitude areas in East Java, Indonesia. J Appl Sci Agric. 9: 81-85.

Utomo, B., R. Oelviani \& Subiharta. 2015. Peningkatan performans pedet sapi Peranakan Ongole pasca sapih melalui perbaikan manajemen dengan pemanfaatan sumber daya lokal. Proceeding Seminar Nasional Masyarakat Biodiversitas Indonesia, 1: 838-842.

Winaya, A., Muladno, R. E. Gunadi, \& A. Saefuddin. 2009. Y chromosome microsatellite variation in Bali cattle (Bos sondaicus) population. Animal Production. 3:149-154.

Wolf, C., J. Rentsch, \& P. Hubner. 1999. PCR-RFLP analysis of mitochondrial DNA: A Reliable Method for Species Identification. J. Agric. Food Chem. 47: 1350-1355. https:// doi.org/10.1021/jf9808426

Yang, W. \& R. J. Tempelman. 2012. A Bayesian antedependence model for whole genome prediction. Genetics 190: 14911501. https://doi.org/10.1534/genetics.111.131540

Zhou, L., X. Ding, Q. Zhang, Y. Wang, M. S. Lund, \& G. Su. 2013. Consistency of linkage disequilibrium between Chinese and Nordic Holsteins and genomic prediction for Chinese Holsteins using a joint reference population. Genet. Sel. Evol. 45:1-7. https://doi.org/10.1186/1297-9686-45-7 